\title{
Yasheng Huang, Selling China : Foreign Investment during the Reform Era
}

New York, Cambridge University Press, 2003, 406 p.

Sandra Poncet

\section{OpenEdition}

\section{Journals}

Édition électronique

URL : http://journals.openedition.org/chinaperspectives/614

DOI : 10.4000/chinaperspectives.614

ISSN : 1996-4617

\section{Éditeur}

Centre d'étude français sur la Chine contemporaine

Édition imprimée

Date de publication : 1 avril 2006

ISSN : 2070-3449

\section{Référence électronique}

Sandra Poncet, "Yasheng Huang, Selling China : Foreign Investment during the Reform Era », China

Perspectives [En ligne], 64 | march - april 2006, mis en ligne le 21 décembre 2006, consulté le 21 septembre 2020. URL : http://journals.openedition.org/chinaperspectives/614 ; DOI : https://doi.org/ 10.4000/chinaperspectives.614

Ce document a été généré automatiquement le 21 septembre 2020

(c) All rights reserved 


\title{
Yasheng Huang, Selling China: Foreign Investment during the Reform Era
}

New York, Cambridge University Press, 2003, 406 p.

\author{
Sandra Poncet
}

\section{NOTE DE L'ÉDITEUR}

Translated from the French original by Jonathan Hall

1 Through his study of the structure of foreign direct investment (FDI), Yasheng Huang offers the reader a fresh analysis of China's economic reforms throughout the 1990s. While acknowledging the beneficial effects of such investments, he distances himself from those works which emphasise China's economic successes. His argument focuses on the costs of the reforms. In his view, the way in which FDI operates in China is more a reflection of the country's institutional weaknesses than of successful economic performance.

2 The author considers the rapid expansion of FDI in China as due to the failure of the reforms to ensure national economic integration and to increase the efficiency of enterprises. By favouring inefficient state enterprises, the government has deliberately (by legal and financial means) created an environment that encourages a disproportionate expansion of FDI. FDI far exceeds the levels that might be expected from the liberalisation process itself or from national economic fundamentals. It plays a much greater role in China than elsewhere, participating in privatisation measures to an extent denied to Chinese firms. Huang's argument is categorical : if the government had not systematically avoided the privatisation of the state enterprises and blocked the development of local private firms, the beneficial effects commonly attributed to FDI (particularly in imported technology) could have been achieved with lower levels of foreign investment. 
3 This original perspective is developed through six remarkably cogent chapters, in which the author shows exemplary restraint in expounding his thesis. His arguments are clearly defined, while he emphasises their limitations and discusses alternative hypotheses that are carefully presented before they are tested against the facts.

His argument gives primacy to the aims and the constraints upon the Chinese enterprises, considering these to be the major factors behind the rapid expansion of FDI. This view of demand contrasts with established views of demand, understood in terms of market access, competitive production costs, or cultural factors. Huang argues that the massive inflow of FDI is more a response to institutional distortions than to competitive opportunities and market dynamics.

Huang's thesis is built upon five anomalies in the Chinese situation, which he identifies in the introductory chapter. The first of these is the disproportionate reliance of China on FDI. Secondly, the simultaneous rapid growth in the transfer of property rights and the drastic reduction in contractual agreements between Chinese and foreign firms is completely unprecedented. Thirdly, Huang emphasises how unusual it is to find exportoriented labour-intensive industries dominated by foreign capital. Traditionally, there is a preference for contractual agreements in this area. The fourth peculiarity concerns the dispersal of FDI across different regions and sectors of the economy, as opposed to the concentrations of capital to be found elsewhere. Finally, the relatively small sums involved in FDI projects, and the disproportionate participation of small and mediumsized investors, run counter to both the forecasts and international practice in general. In his view, these anomalies suggest that FDI in China follow a different dynamic from the generally recognised norm.

6 Having dealt with the different possible explanations (insufficient statistics, potential demand, low production costs), and having outlined his own analytical approach in the second chapter, Yasheng Huang attributes these unprecedented features to three specific institutional characteristics of the Chinese economy. In chapters 3, 4 and 5 respectively, these are defined as the distortions in the allocation of resources due to the financial system, the discriminatory practices arising from a legal system unfavourable to private enterprises, and the fragmentation of the economy caused by restrictions on the movement of goods and capital between the regions.

7 The third chapter gives a precise description of the negative consequences of the laws and policies which favour state over private enterprises. His detailed account of the costs involved in the biased allocation of resources to inefficient state enterprises is very instructive. The consequences of this discrimination against private enterprises are the underdevelopment of private businesses, the low output of the state enterprises, and proliferating miniaturisation.

The next three chapters show the links between these distortions and the five peculiar characteristics of Chinese FDI. They examine in turn how the constraints weighing on the private enterprises (in the form of credit limits and restricted access to the export market) and on the state enterprises (in the form of governmental exactions and impositions of excess labour), in conjunction with the fragmentation of the economy, have pushed Chinese firms into accepting control by foreign capital.

9 The rigorous clarity of exposition in Huang's work deserves the highest praise. His argument is based on case studies from different economic sectors, namely the automobile industry, electrical goods and clothing. These examples allow the reader to 
become familiar with the perverse effects on competitiveness brought about by policies deliberately favouring state enterprises.

Nonetheless, two limitations could be pointed out. Firstly, although the author's tone remains relatively neutral throughout most of his argument, his language loses its objectivity towards the end, when he throws himself into a violent denunciation of official ideology. He believes that the ideological commitment to preserving socialism is the only explanation for the refusal to privatise, and for the distorted allocation of resources. This means that he rejects such alternative explanations as the need to preserve social stability and the political system, or to maximise fiscal receipts, giving credence only to nervous ideological reaction by the authorities.

Recent developments clearly contradict this view. The reforms of ownership in the state enterprises underwent considerable advances in the 1990s. The authorities proceeded to sell a number of state enterprises. Admittedly, these were small and medium-sized ones, but it is nonetheless the case that the share of publicly-owned enterprises in overall production fell rapidly, in favour of enterprises based on increasingly diversified kinds of ownership, such as the limited liability companies, enterprises of which the staff are major shareholders, and completely privatised state enterprises. Not only do these developments undercut Huang's view of the authorities' categorical refusal to privatise, but above all they point to the second limitation to his arguments. Although he believes that the deepening of the reforms will lead to an improving situation for the private sector, and to a reduction of the role played by FDI, his argument does not allow the reader to grasp the speed of these developments. The main source of his data is the third industrial census taken in 1995. Although his report on the situation reflects that period very accurately, it is now rapidly becoming outdated. 